\title{
The Classification Method of Petroleums and Its Application
}

\author{
By Kenzō Satō
}

SYNOPSIS :-The comparison of the evaluation method of oils by U. O. P. characterization factor, viscosity-gravity constant and viscosity index with the classification method of crude oils proposed by U. S. Bureau of Mines was carried out. Then, the author showed the diagram drawn by him for determining the "base" of petroleums by the gravity and boiling temperature or viscosity, and described its application.

The change of nature of crude with the geological age and the depth of well, from whicn it was obtained, was explained according to the data of the oil fields in the world.

Lastly, the importance of investigations at the refineries in this country was pointed out, and a way to improve the present situation was proposed.

\section{オレフインの重合に関する研究（第 1 報） 椰子油, パーム油, 蛹油オレフインの重合}

一一眧相 24 年 9 月 10 日受理一

大阪大学苼業科学研究所 德 永 敏

\begin{abstract}
要旨 脂肪酸の接触热分解に依つて得たオレフィンの無水塩化アルミニシムに依る重合條件並び

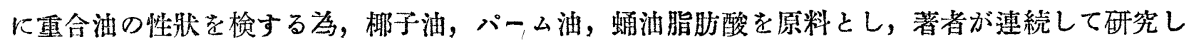
て來た酸化カルシウム或は酸化ベリウムと活性白土混合物に依つて常压下, 気相に於ける接触熱 分解を行い，種々の條件下に粗製オレフィンの精製，無水塩化アルミニウムに依る重合，次て白 土精製重合油のトッピングを行つた後，トッピング残油，トッピング溜出油，重合残租油の性牀 を検し，最す收率良く，且安定な潤滑油を得る重合條件を定めた。オレフィン中に残留するカル

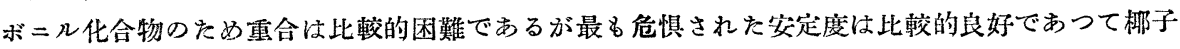
油，パーム油等より比較的收量良く單独にて自動車その他內燃機関用又は自動車発動機用洞滑油 として使用し得るものを合成し得るととを明らかにし，又梛子油オレフィン重合油の平均重合度 を論じた。
\end{abstract}

(I) 緒

鉣油系原料より得たオレフィン，殊に低級オレフィ ンンの雨合に就ては從來より多くの研究発表があり, 桑田，松原両氏は之等に就て綜說的に紹介された。著 者が肪脂酸の蓺分解に関する研究（第6 報）に於て確 証した如く脂肪酸より接触熱分解に㑈つて直接オレフ
ィンを製造する場合，中間生成物と考えられるアルデ ヒド及びケトンの如きカルボニル化合物の残存は避け 難いため，これを重合せしめるときはオレフィンのみ の重合の場合とは趣きを異にしカルボニル化合物の残 存, 重合操作並に重合油の品質, 殊に安定度に対して 一枺の不安をいだかせる。 
此の点を明らかにするため著者は档子油, パーム油”゙ 蛹油脂肪酸の接触熱分解に依つて得たオレフィンを無 水塩化アルミニウムに依つて種々の條件の下に重合 し，重合油の性狀を檢べ叉酸化試驗を行つた結果，オ レフィンの製造並びに精製，重合條件及び電合油の精 製，トノピングの程度等を適当に牂案するときは合成 潤滑油は單独にて自動車々の他內燃戏联用又は自動車 発動機用潤滑油として充分使用し得るものなることを 知つた。

（II） 楖子油脂肪酸より潤滑油の合成
1. 粗製オンフィンの製取 区店管は內渔 $35 \mathrm{~mm}$, 長さ $1,000 \mathrm{~mm}$ の石英管を使用し，これに粒狀とした $25 \% \mathrm{CaO}$ +活性白土或は $15 \% \mathrm{BaO}$ +活性白土混合 一触媒 300 450 cc を充填し, 予熱層 520 370 mm を 設け，触媒量 $300 \mathrm{cc}$ の場合は予熱層を流通気化せし め, 又触媒量 $450 \mathrm{cc}$ の場合は蒸溜法に依つて脂肪酸の 蒸気化を計り分解溫度 $450 \sim 550^{\circ} \mathrm{C}$ にて脂肪酸 $1,000 \mathrm{~g}$ の接触熱分解を行つた。その結果は第 1 表に示寸如く でる。楖子油脂肪酸の性奘は從來のるのと全く同様 である。

\section{第 1 表 楖子油脂肪酸の熱分解並びに分解油の性狀}

\begin{tabular}{|c|c|c|c|c|c|c|c|c|c|}
\hline 亚驗 & 陚料 & 触 & 媒 & 分解溫度 & 分解時間 & 価 & 沃 素 価 & カルホ & \\
\hline 号 & 番号 & 種 & 量(cc) & & $(\min )$ & 倩 & & $=\pi$ 価 & $(\%)$ \\
\hline 215 & A & $\mathrm{BaO}$ 十白士 & 300 & $490 \sim 510$ & 580 & 4.0 & 105.6 & 90 & 67 \\
\hline 216 & B & $\mathrm{CaO}$ 十白土 & 450 & $460 \sim 480$ & 500 & 2.5 & 108.7 & 80 & 65 \\
\hline 217 & $\mathrm{C}$ & $"$ & 300 & $500 \sim 530$ & 330 & 4.0 & 105.5 & 70 & 66 \\
\hline 218 & $\mathrm{D}$ & " & " & $510 \sim 530$ & 290 & 4.5 & 103.7 & 82 & 67 \\
\hline 219 & $\mathrm{E}$ & $\mathrm{BaO}$ 十白土 & 450 & $480 \sim 500$ & 390 & 2.1 & 110.0 & 77 & 63 \\
\hline 220 & F & " & " & $460 \sim 480$ & 460 & 2.0 & 118.0 & 78 & 62 \\
\hline 221 & G & $\mathrm{CaO}+$ 由土 & 300 & $500 \sim 510$ & 580 & 2.7 & 1200 & 77 & $"$ \\
\hline 222 & $\mathrm{H}$ & " & " & $490 \sim 500$ & 460 & 50 & $\cdot 107.0$ & 74 & 64 \\
\hline 223 & I & $"$ & 450 & $470 \sim 490$ & 580 & 2.5 & 108.0 & 80 & " \\
\hline 224 & $\mathrm{~J}$ & " & " & $480 \sim 500$ & 290 & 30 & 103.1 & 81 & 66 \\
\hline 225 & $\mathbf{K}$ & $\mathrm{BaO}$ 十白土 & " & $470 \sim 500$ & 360 & 35 & 1105 & 65 & 62 \\
\hline
\end{tabular}

实騟番号は脂肪酸の熱分解に関する研究(第 1 報)よ收量は粗製オレフィンに対する重量比を以て示し りの通し番号を用いた。

2. 粗製オレフィンの精製 第 1 表に示す各粗製オ レフィンに対し約 30\% に相当寸る小粒狀混合触媒を 添加して，常圧下蒸溜精製したもの>性狀は第 2 表に 示す如くてある。

第 2 表 娜子油オレフインの精製並びに性狀

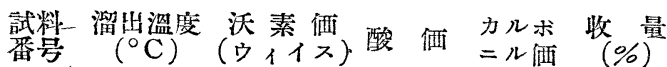

$\begin{array}{lccccc}\mathrm{A} & 220 & 140.4 & 0.2 & 20 & 70 \\ \mathrm{~B} & \text { " } & 141.5 & \text { " } & \text { " } & \text { " } \\ \mathrm{C} & 250 & 135.0 & 0.3 & 27 & 77 \\ \mathrm{D} & \text { " } & 134.7 & \text { " } & 36 & 78 \\ \mathrm{E} & 275 & 130.0 & 02 & 38 & 85 \\ \mathrm{~F} & \text { " } & 128.5 & \text { " } & \text { " } & 86 \\ \mathrm{G} & \text { " } & 129.1 & 0.3 & 35 & 87 \\ \mathrm{H} & 300 & 1205 & 07 & 45 & 92 \\ \mathrm{I} & \text { " } & 121.4 & 05 & 47 & 93 \\ \mathrm{~J} & 275 & 131.0 & 03 & 38, & 85 \\ \mathrm{~K} & 320 & 1125 & 06 & 50 & 97 .\end{array}$
た。この操作により酸価並びにカルホニル洒は低下 し，又溜出したオレフィンの色相は挭めて淡色となつ たが，溜出温度の上昇を共にカルボニ几化合物の残留 も次第に漂加する倾问を示した。

3. 精製オレフィンの重合並びに重合油の精製 以 上の各精製オレフィンを引ロフラスコ內にて無水塩化 アルミシウムを用い種々の條件にて冓合せしめを結果 は第 3 表に示す如くである。

㑇無水塩化アルミニウムも重合溫度の如く，3段階 に分けて添加した。各重合油は暫時靜置した後, 上澄 液を探り 5〜25\%の翰燥活性白土を添加して精製を行 つた。收量 (I )は精製オレフィンに，(II)は粗製オレ フィンに，（III）は原脂肪酸に対する重量比である。

第 3 表に示す如く無水塩化アルミニウムの涯加量が $5 \%$ のときは 25 時間を経るも重合は充分でない。10 特間內に重合油の沃素価を 10 程度に低下せしめるに は無水塩化アルミニウムは少く共 $12 \%$ 以上使用与る 必要があ。又冓合油精製の為に添加す可き活性白土 の量は無水篮化アルミニウムの便用量に依つて異る 
第 3 表 楖子油精製オレフインの重合

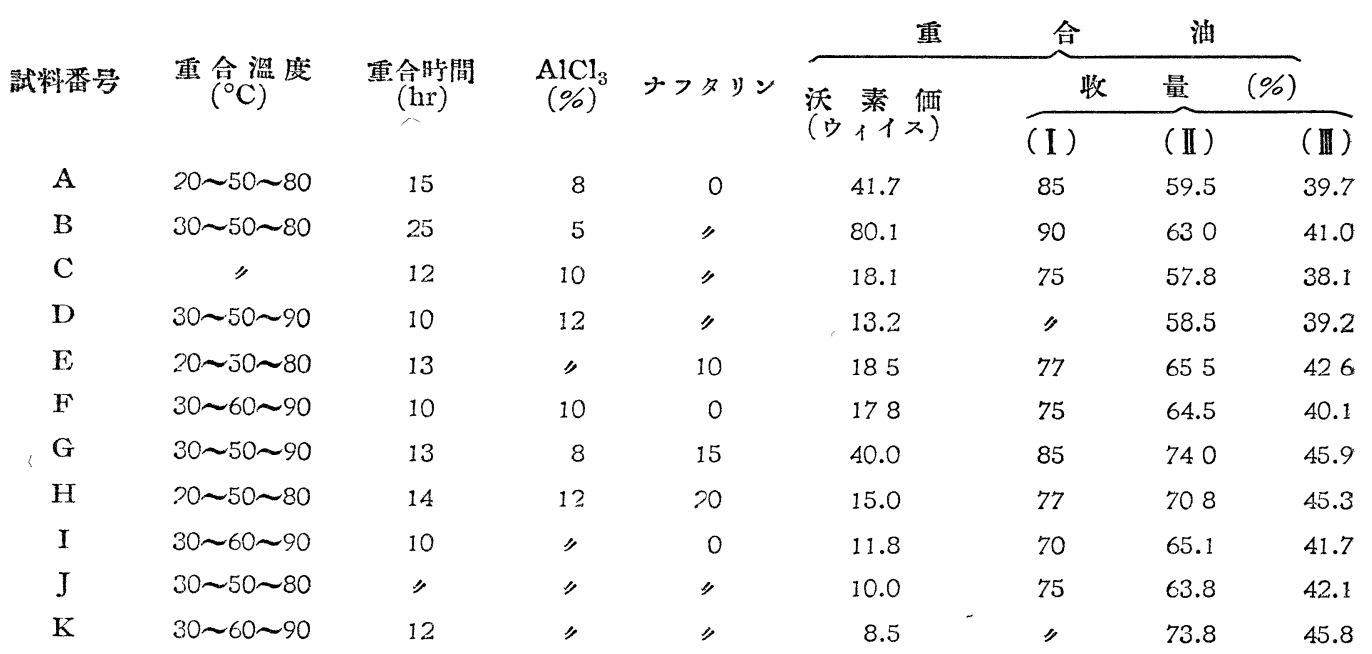

が，無水塩化アルミニウム量が $12 \%$ なるときは白土

は約 20\% 程度添加しなければ脫触䑜は充分でない。

4. 冓合油の性狀

(a) トノピング残油（合成潤滑油）の性狀 各精 製重合油より軽質分を除去するためトノピングを行つ た残油の性狀は第 4 表に示す如くである。

\section{、第 4 表 合成潤滑油の性狀}

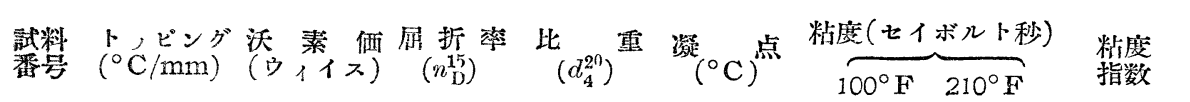

$\begin{array}{lcrrrrrrrrr}\text { A } & 210 / 80 & 43.7 & - & 0.960 & -18 \text { 以 } & 586 & 91 & 136 & 568 & 11.4 \\ \text { B } & 210 / 6: 0 & 72.6 & - & 0,902 & \text { " } & 554 & 80 & 128 & 284 & 66 \\ \text { C } & 240 / 5.0 & 25.0 & 1.4858 & 0.905 & \text { " } & 1,214 & 120 & 118 & 42.8 & 7.1 \\ \text { D } & 250 / 40 & 18.5 & 1.4895 & 0.907 & \text { " } & 1,221 & 126 & 120 & 48.4 & 7.5 \\ \text { E } & 260 / 5.0 & 28.5 & 1.5019 & 0918 & -15 & 1,201 & 129 & \text { " } & 45.9 & 9.9 \\ \text { F } & 250 / 7.0 & 25.1 & 1.4885 & 0.907 & -18 \text { 以下 } & 1,069 & 92 & 99 & 47.3 & 9.2 \\ \text { G } & 250 / 4.0 & 447 & 1.5085 & 0.918 & -12 & 1,431 & 112 & 101 & 350 & 101 \\ \text { H } & \text { " } & 15.5 & 1.5140 & 0.924 & -10 & 1,869 & 113 & 80 & 348 & 8.6 \\ \text { I } & 260 / 50 & 15.1 & 1.4905 & 0905 & -8 & 1,455 & 110 & 98 & 32.6 & 6.2 \\ \text { J } & 250 / 40 & 13.9 & 1.4900 & 0.913 & -18 & 1,581 & 112 & 94 & 36.4 & 7.4 \\ \text { K } & \text { " } & 120 & 15045 & 0.917 & -18 \text { 以下 } & 1,770 & 105 & 71 & 31.2 & 7.9\end{array}$

$\mathrm{A} ， \mathrm{~B}$ の色調は暗赤色，他は何れも青紫色で反応は 閒の酸化後に於ける油の粘度比並びに牫留炭素分を測 何れも中性てあつた。少收量( I )は重合油に対する， (II)は原脂肪酸に対する重量比である。

酸化試驗 精製オレフィン中にカルボニル化合物が 踗められたので合成潤滑油の安定度は鱝重な試驗を必 要とした。試驗法は英国航空省の方法に拋つた。刨ち 供試油約 $40 \mathrm{cc}$ ，を內徑約 $25 \mathrm{~mm}$ の冈㰻狀硝子管に採 り，之を $200 \pm 1^{\circ} \mathrm{C}$ に保つた恒溫油慒に浸し，供試油 中に确子毛細管を通して $151 / \mathrm{hr}$ の流速にて乾燥空気 を吹き达み，之を6時間継続した後，一旦中止し狅日 再び同じ流速にて6甠間吹き込んだ後，この前後12時

\section{第 5 表 酸化試驗結果}

試粠 粘 度 此 酸化 6 時間後 酸化 12 時間後

\begin{tabular}{|c|c|c|c|c|}
\hline 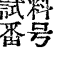 & 粘 度 & 比 & $\begin{array}{c}\text { 酸化 6時間後 } \\
\text { の残留岸素 } \\
(\%) \\
(\%)\end{array}$ & $\begin{array}{c}\text { 酸化12時間 } \\
\text { の残留岸素 } \\
(\%)\end{array}$ \\
\hline D & & 1.93 & 2.17 & 2.96 \\
\hline E & & $279^{\circ}$ & 2.35 & $4.3 i$ \\
\hline F & $3.18 *$ & 305 & 2.29 & 4.15 \\
\hline $\mathrm{H}$ & $2.86^{*}$ & 2.75 & 2.97 & 4.97 \\
\hline I & $3.14^{*}$ & 3.24 & 2.29 & 3.62 \\
\hline $\mathrm{J}$ & & 3.67 & 3.03 & 5.05 \\
\hline
\end{tabular}

* 元第 4 陸軍技庄研究所に於ける洲定值 
定した。残留炭素はコンラードソン試驗器に泝つた。 試科 $\mathrm{D}, \mathrm{E}, \mathrm{F}, \mathrm{H}, \mathrm{I}, \mathrm{J}$ に就て上逃の試驗を行つた 結果は第 5 表に示寸如くてある。

デーゼル発動機冬期用モビール油として要求せられ る粘度は第 4 表に示寸試料 $A, B, F$, 文夏季用モ七一 儿油としては $\mathrm{A} ， \mathrm{~F} ， \mathrm{~K}$ 程度のもの力適当あつて他は何 れも粘度が大に過ぎる。郎ち粗製オレフィンを $275^{\circ} \mathrm{C}$ 汽に溜出させて精製を行い，之を $10 \%$ の無水塩化ア ルミニウムを以て重合時間 10 時間にて30〜60 90 $90^{\circ} \mathrm{C}$ の3段階に分ちて重合を行つた後（この㭙の重合油の 沃素価約 18), 乾燥活性白士 $10 \%$ を加之 $150 \sim 160^{\circ} \mathrm{C}$ にて 5 分間加熱，精製を行つたものを $250^{\circ} \mathrm{C} / 7.0 \mathrm{~mm}$ にてトノピングを行つたものでるる。

又自動車用モビールとしては各試料共粘度が過大で あつて，更に軽度のト，ピングに依つて適性油を製收 し得る見达であり，從つて原脂肪酸に対する收量は遥 かに大となる。又粘度指数並びに安定度は粗製オレフ イン蒸溜皿度の上舁と共に一般に低下することか認め られた。

（b）トピング溜出油の性枵 各試料のトノピン グに際して溜出する俥質油は第6 表に示す如くであ る。
第 6 表 トツピング畾出油の性狀 ( I )

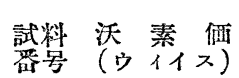

A $\quad 308$

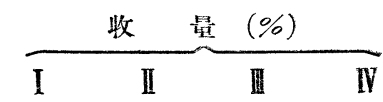

$\begin{array}{llllll}\text { B } & 84.9 & 66.8 & 60.1 & 47.7 & 19.5\end{array}$

$\begin{array}{lll}412 & 34.1 \quad 207\end{array}$

8.3

$\begin{array}{llllll}\text { C } & 14.1 & 56.0 & 42.0 & 243 & 9.3\end{array}$

$\begin{array}{llllll}\mathrm{D} & 29.9 & 55.7 & 41.8 & 244 & 9.6\end{array}$

$\begin{array}{llllll}\text { E } & 12.1 & 520 & 40.0 & 262 & 11.2\end{array}$

$\begin{array}{llllll}\mathrm{F} & 10.1 & 51.6 & 38.7 & 250 & 10.0\end{array}$

$\begin{array}{llllll}\mathrm{G} & 33.5 & 648 & 55.1 & 408 & 18.7\end{array}$

$\begin{array}{llllll}\mathrm{H} & 13.0 & 65.2 & 50.2 & 355 & 16.1\end{array}$

$\begin{array}{llllll}\text { I } & 80 & 592 & 41.5 & 27.0 & 11.3\end{array}$

$\begin{array}{llllll}\mathrm{J} & - & 62.3 & 46.7 & 29.8 & 12.5\end{array}$

$\begin{array}{llllll}\mathrm{K} & 6.5^{-} & 61.2^{-} & 45.9 & 339 & 15.5\end{array}$

I：原重合油に対する重量比。

II：精製オレフィンに対する重量比。

些：粗製オレフィンK対する重量比。

IV：原脂䏚酸火対する重量比。

色調は何れも㷋黃乃至谈赤橙色てある。

次に A， B， G 除く各溜出油を合一したもの $420 \mathrm{~g}$ （沃素価 8.0，電気絕線恒数 $1.8 \times 10^{-1:} \Omega$ ） を $15 \mathrm{~mm}$ $\mathrm{Hg}$ 減圧にて蒸溜し，次に残部に就て $60 \mathrm{~mm} \mathrm{Hg}$ に て分溜した結果は第 7 表に示す如くてある。

\section{第 7 表 トツピソグ溜出油の性狀（II）}

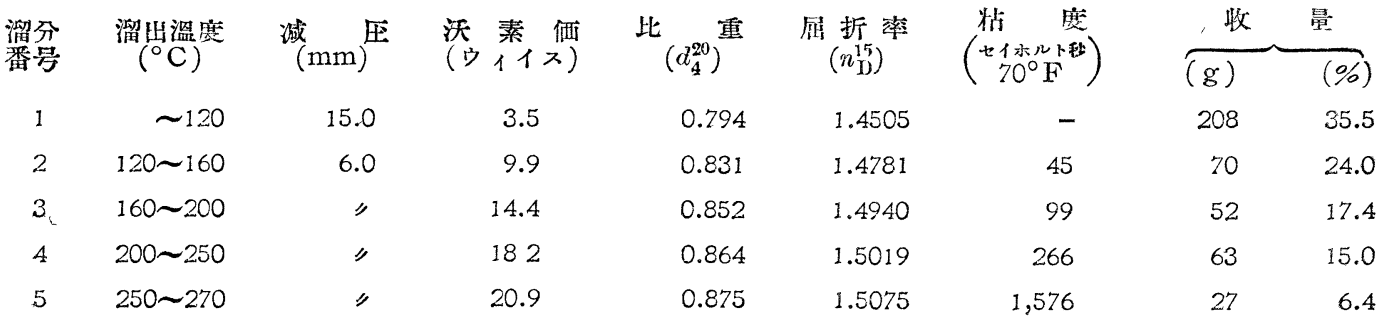

以上の各溜分の中，第（3）溜分の粘度（レ，ドゥ , ド秒 $50^{\circ} \mathrm{C}$ ) 63 , 凝点 $-18^{\circ} \mathrm{C}$ 以下及び引火点 (ぺ ンスキー・マルテン試驗器) $210^{\circ} \mathrm{C}$ はスピントル油の 日本檩準規格に合致するものてある。

（c）重合残查油の性狀 試料 A, B, G を除く各 重合残查油を全部合一し，充分湯洗脫触蝶した暗褐色 油は，届折率 $\left(n_{\mathrm{D}}^{15}\right) 1.5065$, 比重 $\left(d_{4}^{15}\right) 0.895$, 沃素洒 (ウィイス) 44.7，粘度(セイホルト秒) $100^{\circ} \mathrm{F}$ で 550 , $210^{\circ} \mathrm{F}$ で 560 , 粘度指数 29 , 凝固点 $0^{\circ} \mathrm{C}$ てあつて これに蒸溜精製或は水添等を行之はマシン油として充 分使用し得るものと思われる。

(d) 重合油の平均重合度 上述の如き重合條件に てて脂肪酸より製取したオレフィン重合油の平均重合度

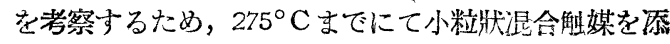
加して，蒸溜精製を行つた精製オレフィン（沃素価

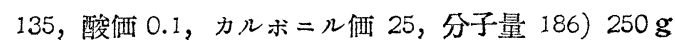
宛老重合溫度 20〜50 9 $90^{\circ} \mathrm{C}$ に無水塩化アルミニ ム9\%を3等分して添加して重合したものの上澄液に 対し，15\%の乾燥活性白土を添加し，150 $160^{\circ} \mathrm{C}$ に

\section{第 8 表重合油の性狀}

\begin{tabular}{|c|c|c|c|c|}
\hline 試科 & $\begin{array}{l}\text { 重合時間 } \\
\text { (hr) }\end{array}$ & $\begin{array}{l}\text { 沃素 価 } \\
\text { (ウイイス) }\end{array}$ & 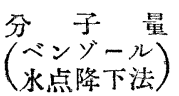 & )$^{\text {收 }}(\%)$ \\
\hline 1 & 6 & 61.0 & 292 & 85 \\
\hline 2 & 9 & 40.5 & 360 & 80 \\
\hline 3 & 12 & 170 & 590 & 77 \\
\hline 4 & 15 & 9.0 & 1,030 & 75 \\
\hline
\end{tabular}


て 5 分間加垁後瀘過した結果は第 8 表に示す如くであ る。

以上の結果より各重合油の平均重合度を推察すると 試料 1, 2, 3, 4 は夫夕 $1.5,2.0,3.0,5.5$ 分子重合と なる。

次に各重合油 $175 \mathrm{~g}$ 宛を最初 $15 \mathrm{~mm} \mathrm{Hg} に$ ，次 に $5 \mathrm{~mm} \mathrm{Hg}$ にて分溜した結果は第9表に示す如くで ある。

\section{第 9 表 重合油の分溜結果}

武料溜分溜出温度減压沃素価分子量收量

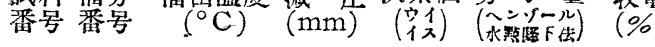

\begin{tabular}{|c|c|c|c|c|c|c|}
\hline 1 & 1 & $\sim 120$ & 15 & 5.5 & 170 & 24. \\
\hline & 2 & $120 \sim 150$ & 5 & 53.5 & 215 & 15.5 \\
\hline & 3 & $150 \sim 200$ & $"$ & 61.2 & 300 & \\
\hline & 4 & $200 \sim 240$ & $"$ & 65.0 & 350 & \\
\hline & - & 残 油 & - & 73.0 & 380 & \\
\hline 2 & 1 & $\sim 120$ & 15 & 5.0 & 165 & \\
\hline & 2 & $120 \sim 150$ & 5 & 40.6 & 250 & \\
\hline & 3 & $150 \sim 200$ & $"$ & 43.1 & 320 & \\
\hline & 4 & $200 \sim 240$ & $"$ & 50.0 & 365 & \\
\hline & - & 残 油 & - & 58.1 & 560 & \\
\hline & 1 & $\sim 120$ & 15 & 4.8 & 178 & 24 \\
\hline & 2 & $120 \sim 150$ & 5 & 12.1 & 248 & \\
\hline & 3 & $150 \sim 200$ & $"$ & 14.1 & 335 & \\
\hline & 4 & $200 \sim 240$ & " & 21.7 & 400 & \\
\hline & - & 残 油 & - & 25.0 & 1,020 & 30 \\
\hline & 1 & $\sim 120$ & 15 & 4.5 & 160 & 4 \\
\hline & 2 & $120 \sim 150$ & 5 & 9.0 & 280 & \\
\hline & 3 & $150 \sim 200$ & $"$ & 9.1 & 350 & \\
\hline & $-x$ & $200 \sim 240$ & " & 11.1 & 500 & \\
\hline & - & 残 油 & - & 13.0 & 1,950 & \\
\hline
\end{tabular}

以上の結果からトッピング残油の原オレフィンに対 する平均重合度は夫々 $2,3,5,10$ 分子重合している ものと推察される。尙此処に云万重合とは傎の意味の 重合ではなく縮合，環化，異泩化及び覓の重合等の複 雜な反応を一括したものである。

纷以上の結果に依つて明らかな如く第（1）溜分が 次第に墰加することより，重合が進むと共に塩化アル ミニウムによる重合油の分解する傾问が明らかに認め られた。

（II） パーム油脂肪酸より潤滑油の合成

1. 耝製オレフィンの製取 內俓 $35 \mathrm{~mm}$, 長さ 1,000 $\mathrm{mm}$ の石英管に小粒狀 $25 \% \mathrm{CaO}$ 活性白土混合触媒 $450 \mathrm{cc}$ を充填し, 牛速続的に蒸溜を行つて脂肪酸の蒸

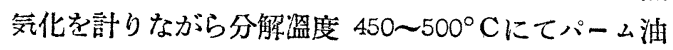

脂肪酸 $1,000 \mathrm{~g}$ の接触熱分解を行つた結果は第 10 表 に示す如くである。

\section{第 10 表 パーム淄脂助酸の熱分解} 並びに分解油の性狀

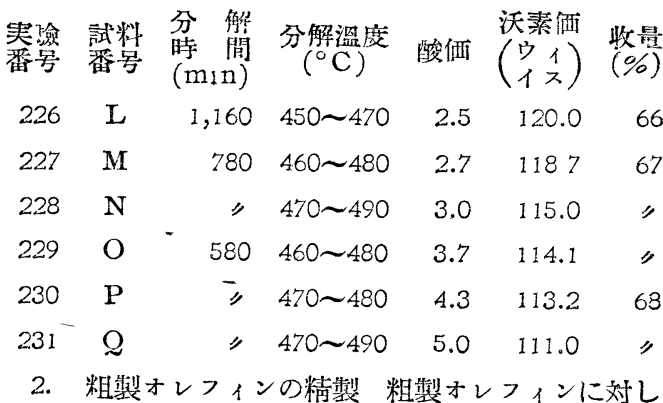
約 30\% に相当与る $25 \% \mathrm{CaO}+$ 活性白土の小粒狀物 を添加して蒝溜精製を行つた結果は第 11 表に示寸如 くである。

第11 表 パーム油オレフインの精製並びに性狀

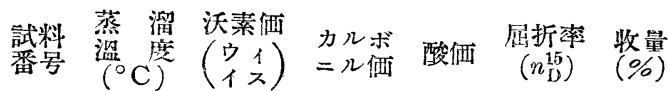
$\begin{array}{lllllll}\mathrm{L} & 225 & 139.6 & 25.4 & 0.3 & 1.4649 & 74\end{array}$ $\begin{array}{lllllll}\text { M } & 275 & 133.1 & 37.8 & 0.5 & 1.4658 & 88\end{array}$ $\begin{array}{lllllll}\mathrm{N} & 300 & 134.4 & 44.3 & 0.7 & 1.4662 & 94\end{array}$ $\begin{array}{lllllll}\mathrm{O} & \text { " } & 131.5 & 35.8 & 1.0 & 1.4656 & 95\end{array}$ $\mathrm{P} \quad$ " $127.1 \quad 47.6 \quad 1.7 \quad$ - 94 $\begin{array}{lllllll}\mathrm{Q} & 320 & 105.5 & 50.4 & 2.1 & - & 98\end{array}$

郎ち酸㽪並びにカルボニル洒は减少し精製目的を澾 した。

3. 精製オレフィンの重合 第 11 表に示す各精製 オレフィンを無水塩化アルミニウムにて重合せしめ， ヌナフタリンそ縮合せしめた結果は第 12 表に示す如 くである。但し重合溫度は 20〜50 $80^{\circ} \mathrm{C}$ の 3 段階に 分ち，從つて重合劑の添加甩 3 回に分割して添加し た。又重合時間は何れも 12 時間とした。

\section{第12表 パーム油綪製オレフインの重合} 試料番号 $\underset{(\%)}{\mathrm{AiCl}_{3}}$ ナフタリン 重命油の沃素洒

$\begin{array}{lccc}\mathrm{L} & 10 & 0 & 32.5 \\ \mathrm{M} & " & " & 24.3 \\ \mathrm{~N} & 12 & " & 22.2 \\ \mathrm{O} & " & " & 18.9 \\ \mathrm{P} & 14 & 5 & 9.7 \\ \mathrm{Q} & 13 & 10 & 10.0\end{array}$

4. 重合油のトーピング垡油の性状 各重命油のト ノピング牫油の性狀は次頁の第 13 表に示寸如くであ る。 


\section{第 13 表 合成潤滑油の性狀}

\begin{tabular}{|c|c|c|c|c|c|c|c|c|c|}
\hline $\begin{array}{l}\text { 試粘 } \\
\text { 番号 }\end{array}$ & $\begin{array}{l}\text { ドピング } \\
\left({ }^{\circ} \mathrm{C} / \mathrm{mm}\right)\end{array}$ & $\begin{array}{l}\text { 沃素価 } \\
\text { (ウィイス) }\end{array}$ & $\begin{array}{c}\text { 度 折 率 } \\
\left(n_{\mathrm{D}}^{15}\right)\end{array}$ & 比 $\left(d_{4}^{20}\right)^{\text {重 }}$ & $\left.{ }^{\circ}{ }^{\circ} \mathrm{C}\right)$ & $\frac{\text { 粘度(七) }}{100^{\circ} \mathrm{F}}$ & $\frac{2 ル ト \text { 秒) }}{210^{\circ} \mathrm{F}}$ & 亃度指数 & 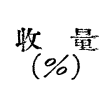 \\
\hline I & $270 / 8.0$ & 51.3 & 1.5165 & 0.910 & -18以下 & 1,203 & 125 & 123 & 20 \\
\hline $\mathrm{M}$ & $255 / 5.0$ & 37.3 & 1.5232 & 0.912 & " & 1,215 & 110 & 110 & 22 \\
\hline $\mathrm{N}$ & $270 / 9.0$ & 30.3 & 1.5211 & 0.906 & -18 & 1,068 & 101 & 109 & 25 \\
\hline $\mathrm{O}$ & $250 / 4.0$ & 25.9 & 1.5279 & 0.912 & -15 & 1,581 & 112 & 94 & 15 \\
\hline $\mathbf{P}$ & $240,5.0$ & 12.5 & 1.5311 & 0.911 & " & 1,427 & 107 & 106 & 18 \\
\hline$Q$ & $240 / 5.0$ & 15.8 & 1.5380 & 0.916 & -10 & 1,375 & 97 & 82 & 20 \\
\hline
\end{tabular}

收量は声製オレフィンに対寸る重合比で示した。 酸化試驗 第 13 表に示寸各試料に就き穴定度試驗 を行つた結果は第 14 表に示す如くである。

\section{第14表 酸化試驗結果}

試料番号 粘 度 此酸化 6㛀間後の 酸化12時間後の

$\begin{array}{llll}\mathrm{L} & 1.89 & 3.99 & 5.06 \\ \mathrm{M} & 2.75 & 2.66 & 4.47 \\ \mathrm{~N} & 2.70 & 2.17 & 4.38 \\ \mathrm{O} & 3.11 & 3.85 & 5.17 \\ \mathrm{P} & 2.78 & 3.52 & 4.55 \\ \mathrm{Q} & 2.98 & 3.87 & 5.33\end{array}$

以上の結果を考察するに，棑子油脂肪酸の場命々同 樣に粗製オレフィンの蒸溜溫度低いものは䉼度指数, 安定度其に一般に良好である。これは粗製オレフィン

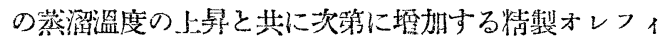
ン中のカルホニル化合物に原因するものと思われる。 酸化に依る孷化分は不饱和度の高い必の程多くなる。

以上の結果を綜合してパーム油脂肪酸より变者の方 洗に依つて高級モビール油の規格に適合与るものを合 成することは充分可能で女る。

（IV）蛹油オレフインょり潤滑油の合成

1. 反応管は何れも內㹵 $35 \mathrm{~mm}$ ，長さ $1,000 \mathrm{~mm}$ の

石英管党使用し，これに小粒狀とした $25 \% \mathrm{CaO}$ +活 性白土混令物約 $300 \mathrm{cc}$ を充塤し，预熱層を流通也し めて脂肤酸の蒸気化を計りながら教分解を行つた結果 は第 15 表に示す如くである。但し脂肪酸量は海回 $1,000 \mathrm{~g}$ とした。

第 15 表 蛹油脂助酸の分解並びに分解油の性狀

\begin{tabular}{|c|c|c|c|c|c|}
\hline 驗 & $\begin{array}{c}\text { 分解時間 } \\
\text { (min) }\end{array}$ & $\begin{array}{c}\text { 分解溫度 } \\
\left({ }^{\circ}\right)\end{array}$ & 酸 洒 & $\begin{array}{l}\text { 素 価 } \\
\text { ウイスイ) }\end{array}$ & 量 \\
\hline & 750 & $470 \sim 490$ & 23.5 & 102.5 & \\
\hline & 550 & $480 \sim 500$ & 35.5 & 100.0 & \\
\hline & 435 & $490 \sim 510$ & 40.0 & 94.1. & \\
\hline
\end{tabular}

2. 精製オレフィンの重合並びにトピング残油の 性爿 第15表に示寸各粗製オレフィンに対し約 30\% に相当する小粒狀混合触媒起添加し，蒸溜䊁製を行つ

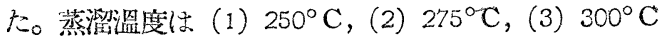
(試料番号夫々 R, S, T. 沃素酒 $145.0 ， 135.0 ， 113.3$ ) とし忠。無水塩化アルミニウムの添加は $12 \%$ とし, 又重合溫度は 30〜50 $80^{\circ} \mathrm{C}$ の 3 段階とした。全重合 時間を何れも 15 時間とし重合終了後, 上登液に乾燥 活性白土約 $20 \%$ を加之，150 $160^{\circ} \mathrm{C}$ にて約 5 分間 加熱して精製した重合油を， $250^{\circ} \mathrm{C} / 4.0 \mathrm{~mm}$ にてト， ピングを行つた残油の性狀は第 16 表に示す如くであ る。

\section{第 16 表 合成潤滑油の性狀}

\begin{tabular}{|c|c|c|c|c|c|c|c|c|}
\hline \multirow{2}{*}{$\begin{array}{l}\text { 試料 } \\
\text { 番号 }\end{array}$} & \multirow{2}{*}{$\begin{array}{l}\text { 渠 価 } \\
(ウ 1 イ ス)\end{array}$} & \multirow{2}{*}{$\begin{array}{c}\text { 属折 崇 } \\
\left(n_{\mathrm{D}}^{15}\right)\end{array}$} & \multirow{2}{*}{ 比 $\left(d_{4}^{20}\right)^{\text {重 }}$} & \multirow{2}{*}{${ }^{\text {凝 }}\left({ }^{\circ} \mathrm{C}\right)^{\text {点 }}$} & \multicolumn{2}{|c|}{ 粘度(セイボルト秒) } & \multirow{2}{*}{ 粘度指数 } & \multirow{2}{*}{$\begin{array}{c}\text { 收 量 } \\
(\%)\end{array}$} \\
\hline & & & & & $100^{\circ} \mathrm{F}$ & $210^{\circ} \mathrm{F}$ & & \\
\hline $\mathrm{R}$ & 55.1 & 1.5121 & 0.908 & -18以下 & 1,200 & 118 & 119 & 10 \\
\hline s & 40.1 & 1.5225 & 0.910 & " & 1,211 & 120 & 118 & 11 \\
\hline & 33.3 & 1.5231 & 0.911 & -18 & 1,285 & 122 & " & 13 \\
\hline
\end{tabular}

收量は精製オレフィンに対する重量比でせつて，䉽 するに起因する。然し乍ら收得した潤滑油は梛子油， パーム油脂肪酸の場合に比して著しい相違は認められ ない。

く同一蓧件にて精製オレフィンの重合を行万も重合程 度は遥かに低く，沃素価の隇少は小である。之等は粗 製オレフィンの製取にあたり，蛹油脂肪酸中のリノー 几酸, リノレン酸が分解し，低級炭化水素が多量生成

\section{(V) 临括}

著者の方法に依つて椰子油, パーム油, 蛹油脂肪酸 より粗製オレフィンを製し，これを更に種々の溫度迄 
蒸溜精製した後，無水塩化アルミニウムに体つて重合 し，又はナフタリンと縮合することに恢つて日本標準 規格に合格する高級潤滑油を合成し得ること，並びに 良質の潤滑油を收量良く得んとする場合の最適製造條 件を明らかにし，又楖子油オレフィンに就て無水塩化 アルミンウムに体る重合油の平均重合度に就て論じ た。

本研究に対し御孤篤な御指導を賜つた大阪大学名譽 教授工学博士上野誠一先生並びに本論文発表にあたり
種々御助言を戴いた大阪大学教授堤繁博士: に深謝す る。又本報告の姴旨は工業化学会，第 48 年会に於て 講演した。本報告を「動植物油脂より潤滑油合成に関 する研究(第 8 報)」とする。

\section{文献}

（1）桑田勉，松原文雄，本誌，19，1940，618。

（2）德永，日本油脂技㙝誌，3，1950，89.

（3）德永，日本油脂技協誌，3，1950，37。

\section{On the Polymerization of Olefines Produced from Some Fatty Acids (I)}

The Synthesis of Lubricating Oil from the Fatty

\section{Acids of Coconut, Palm and Chrysalis Oil}

\section{By Toshiichi Tokunaga}

(The Inst. of Sci. and Ind. Research, Osaka University)

SYNOPSIS :-The author described on the details of the characteristics of synthetic lubricating oils from the olefines which were prepared by the decomposition and refining of the fatty acids of coconut, palm and chrysalis oil, and also discussed the optimum conditions of preparation.

The decompositions were carried out on the following conditions: the reactions :vapour phase, pressures:-atmospheric, decomposition agents:-the mixture of $100 \%$ active clay and $25 \%$ calciumoxide or bariumoxide, and temperatures; - about 450 $500^{\circ} \mathrm{C}$. The polymerization agent of refined olefine was anhydrous aluminium chloride.

The stabilities of these synthetic lubricating oils were examined in detail and they were recognized as the good lubricating oil for automobile or other internal combustion engines.

\section{アメリカの製鋼能力引上}

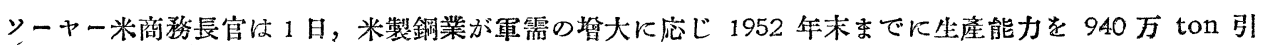
上げるだろらと発表した。これは 2 年間に生產能力を 1 割近く塤大するととになり，第 2 次大戰当時の增

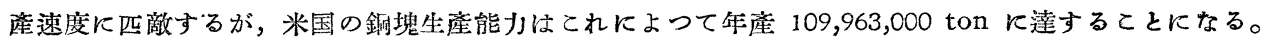
な指との数字はソーャー長官からの增產要請に対し米鉄銅協会から提出されたもので，業界筇によれば 以上の箸產計画は政府の援助を受けず製銅 20 社がみずからの力で実行するものとされている。 